DOI https://doi.org/10.36059/978-966-397-113-1/65-89

\title{
THE GENESIS OF CORRUPTION CRIME IN UKRAINE IN THE CONTEXT OF THE STATE CRIMINALIZATION
}

\section{Busol O. Yu.}

\section{INTRODUCTION}

Such a negative social phenomenon as corruption is a sort of the disease of the society that has affected politics, state authorities, economics, as well as financial, social and cultural spheres. That is why it has a very negative effect on the democratic development of the state, which is a threat to its national security. It is not possible to fight against such "disease" without knowing its essence, the causes of its origin in detail and course of action to be taken. The search for a solution to the problems of combating organized crime and corruption exclusively by criminal means is a utopian idea. A relatively large number of law enforcement bodies have already been set up in Ukraine. Huge amounts of money are spent on maintaining newly created bodies. At the same time, their effectiveness in combating corruption remains very low. Law enforcement officers do not make the necessary efforts to detect transnational criminal organizations, but are engaged in combating small organized groups and subgroups instead. Besides, the Ukrainian lawenforcement bodies after being reformed have changed more in form than in essence and still have a lot of problems, in particular, the problems related to duplicating their functions and coordination of interagency.

Organized corruption in Ukraine has an ancient background. It has gone a long way from being primitive to becoming perfect one. At each stage of development there was a transformation of its form and essence.

\section{Historical background to the origin of corruption crime in Ukraine}

The stage of origin and formation of organized crime in our state began during the period of time when Ukraine was part of the Soviet Union in the 40's - 50's and subsequent years as well. It was preceded by professional crime, which has a much longer history. In the late 50's and 60 's organized crime started to form new economic structures - various artels, whose purpose was to become rich in illegal way. In particular, the 
«Trudovyk» artel in the Lviv region was quite indicative one in this respect. In 1961, as a result of an investigation carried out by the Prosecutor's Office, a number of employees of this structure were arrested for theft of public funds in particularly large amounts, of which 8 were subsequently sentenced to an exceptional punishment, i.e. execution by firing squad ${ }^{1}$. The structure of the Lviv artel «Trudovyk» consisted of about nineteen people. The foundation of such a company fell into the category of ideologically harmful phenomena, but at that time, when Lviv was considered the outskirts, it was possible to be done, since they had more freedom in following the law or not. The production of clothes and accessories by the labor artel could not even be called underground one. Some things were produced quite legally. The artel was hiding from the state only the volume of its successful production. Business very quickly became not only cost effective, but also very profitable and lucrative, and therefore the artels were carried away way too much by that fact. They became obsessed with that so much that they forgot in what country were their tailor's shops. As a result, in 1961, a whole group of nineteen people was arrested. Although they were accused of theft, in reality, this was not entirely the case. The fact is that in the USSR the legal framework for making a successful business did not exist; besides the very opportunity for individuals to get rich fundamentally contradicted the socialist economy in whole. At court, the artels were accused of stealing public funds worth almost two million UAH. As a result of such huge amounts, eight members of the artel were sentenced to execution by firing squad. This caused public astonishment, because they produced goods under officially registered artel, that is, their activities were sanctioned by the state itself, which subsequently passed such verdict. The strange fact was also that the raw materials from which they produced raincoats and costumes were bought at the warehouse.

Since the introduction of the new economic policy (NEP) the legislative base of the USSR did not eliminate some loopholes that allowed making private production. The psychology of those people and methods of work differed significantly from the psychology and methods of the shadow economy operators of the later period. They did not put

\footnotetext{
${ }^{1}$ Романюк Б.В. Трансформація сучасної організованої злочинності в Україні. Україна в системі сучасного міжнародного правопорядку та Європейської інтеграції: загальнотеоретичні та практичні проблеми: матеріали міжнар. наук.-практ.конф., м. Київ, 18 груд. 2018 р. Київ: Таврійський національний університет імені В. І. Вернадського. 2018. 204 с.
} 
themselves in the official opposition to the Criminal Code, unlike the black marketeers that came to replace them during the «stagnant» period. They knew perfectly well that the judges, who sentenced the verdict, would not actually care how much and what kind of goods the shadow economy operators made, since production volumes there did not play any role. After all, the raw material was acquired through the theft of state property; besides, the permissive basis for private production no longer existed in the USSR at that time. However, the fact of the criminogenic nature of their actions did not stop any of the shadow economy operators anyway.

In the 70's and 80's organized crime was already using a corruption as an instrument, including also supreme state bodies. Criminal proceedings against some high-ranking officials of the USSR, also heads of Uzbekistan and other Central Asian republics are quite noteworthy. Therefore, it is not unexpected that in November 1985 for the first time at the College of the Ministry of Internal Affairs of the USSR the fact of organized crime in the state was recognized.

The stage of systemic accumulation of primary capital (late 1980s early 1990s) is characterized by the introduction of so-called reformation period at that time in the USSR, which was associated with some weakening in public administration, including also economy and financial spheres. It was allowed to create private cooperatives for various types of activities. Cooperatives did not have any sufficient material base and raw materials, therefore, their leaders entered into unlawful dealings with state-owned enterprises, banks to use their resources for their own activities and enrichment. The law enforcement authorities were even strictly banned for quite a long time to check up the activities of these new economic or financial institutions under the guise of creating favorable conditions for their development. Racket, speculation, currency exchange and other shadow activities were widely spread all over the state. On the other hand, there was an unjustified sharp release of prices for consumer goods at that time, which led to the impoverishment of the population. In addition, most citizens lost their money savings in savings banks. Such situation was happening in the period of uncontrolled development of cooperation and state industry. At that time, the state monopoly on foreign trade, alcohol production, etc. was eliminated 
Poor and non-rational reforms of the independent by that time Ukraine could not provide a reliable protection against the activities of organized criminal groups; moreover they even promoted them in some way or another. As the researchers point out, it was during that period of time that the first manifestations of criminal elements, which were merged with criminals in the economy and finance spheres, were dated. This led to the emergence of a shadow economy, «white-collar» crime; and the process of involvement of certain employees of the state apparatus and law enforcement bodies ${ }^{2}$ in the criminal activities started also at that time. It was exactly at that time that some of the still scattered criminal groups started to accumulate their primary capital and professional potential. Due to such situation, in 1985, the first divisions of combating organized crime were set up within the structure of the Ministry of Internal Affairs of Ukraine, so, the special interdepartmental body, namely the Coordinating Committee on Combating Corruption and Organized Crime was created. At that time, the state and law enforcement bodies were able to significantly influence the manifestations of organized crime, but mainly it involved organized criminal groups engaged in racketeering and other forms of extortion. Such well-known organized criminal groups as «Avdisheva», «Kiselya», «Savlochi» and others were detected and brought to criminal responsibility. This was the period when the first attempts to launder money of illicit enrichment took place. But during that time newly created state and law-enforcement bodies of independent Ukraine have not yet been so effective in influencing the real organized crime due to their inadequate qualifications. The organized crime was undergoing significant transformational processes which had become more «professional» then. Due to the dubious activity of some politicians, the criminal legislation directed law enforcement officers to expose the lowest levels of organized crime ${ }^{3}$.

The stage, when criminalization of the society started (1993-1995). During this period, the majority of new business entities and a large part of state-owned enterprises were taken over by the racketeering groups. Transnational clans have significantly influenced the distribution of

\footnotetext{
${ }^{2}$ Кримінологія. Спеціалізований курс лекцій зі схемами : Загальна та Особлива частини : [навч. посібн.] / Джужа О.М., Моісеєв С.М., Василевич В.В. К. : Атіка, 2001. 172 с.

${ }^{3}$ Романюк Б.В. Трансформація сучасної організованої злочинності в Україні. Україна в системі сучасного міжнародного правопорядку та Європейської інтеграції: загальнотеоретичні та практичні проблеми: Матеріали міжнар. наук.-практ. конф., м. Київ, 18 груд. 2018 р. Київ: Таврійський національний університет імені В. І. Вернадського. 2018. С. 155, 156.
} 
marketable products in the Ukrainian market. Up to 3 billion US dollars were illegally exported annually from Ukraine, which constituted almost $50 \%$ of legal exports in 1993. The state apparatus, including its law enforcement agencies, more and more was merging with semi-criminal clans and losing the immunity of protection against criminal acts. In fact, not only the shadow sector in the economy was formed in Ukraine, but also the illegal Fifth Estate was formed, which began to duplicate the most important functions of the state. In the period from 1994 to 1995, none of the problems was given as much attention by the government as the combating the criminalization of the society. All this, of course, contributed to the mobilization of public opinion and created an unfavorable public environment for the activities of the Fifth Estate. However, political declarations were supported also by practical steps. Given the insufficient staffing, financial, material, legal capabilities of individual law enforcement bodies, also the possible pressure on them by high officials, as well as the direct connection of part of law enforcement with criminality, they placed a premium on special interdepartmental operational investigation teams under the General Prosecutor's Office of Ukraine.

The results of the research by the experts of the Ukrainian Center for Economic and Political Studies named after O. Razumkov and also by a number of other domestic and international independent organizations, give us grounds to suggest that they did not succeed much in breaking the tendency of criminalization of the state, as well as its economy and political infrastructure. The basis for such conclusions is the analysis of the development of the shadow economy in Ukraine, which share significantly exceeded $50 \%$ then. A similar level of the shadow sector (i.e. $50 \%$ of GDP) was also stated by World Bank experts ${ }^{4}$. According to official statistics, about UAH 230 trillion was in the outbound bank circulation ( $40 \%$ of the total money supply of the state). At the same time, it should be taken into account that a significant amount of shadow commodity-currency transactions were carried out in Ukraine with the use of foreign currencies, namely US dollars in the first place. This currency money supply was not controlled by the state at all. At the same time, according to A.Paskhaver estimates, more than USD 10 billion of cash was accumulated in Ukraine at that time.

\footnotetext{
${ }^{4}$ Даніель Кауфман.Час-time. 08.12.95.
} 
According to the data of the National Bank of Ukraine, the volumes of foreign currency cash usage in Ukraine are as follows: in October 1994 the volume of foreign currency exchange amounted to USD 70 million, in December 1994 - it was already USD 211 million, and in August 1995 USD 868 million. At the end of 1995, the volume of Russian rubles exchange constituted $7 \%$ of the total money supply, and in September 1995 it accounted for more than $20 \%$ already. Thus, in 1995, the process of shadowing the economy was not stopped. Moreover, the shadow economy sector has grown by at least $25-30 \%$ (as compared to 1994) and has reached such a limit when the state has lost the possibility of a real impact on economic processes. The economy has become almost unmanageable. Half of the economic potential functioned uncontrollable or under the direct control of criminal structures and was not subordinate to the state.

At the same time, the entire shadow economy cannot be only identified with the criminal one. The shadow economy is also a result of the search of enterprises for ways of self-preservation in the conditions of total tax pressure, which makes it impossible for them to function in the legal field. It is the shadow economy that has helped to prevent the collapse of hundreds of industrial and agricultural enterprises and to save at least $2 / 3$ of Ukrainian citizens from impoverishment.

The head of the SSU (the Security Service of Ukraine) A.Radchenko noted that for 2.5 million Ukrainian citizens the shadow economy was the main source of income and that up to $40 \%$ of young people in large cities and border regions were employed in the shadow sector ${ }^{5}$. The criminal sector is characterized by deliberate evasion from the actions of state regulators, the redistribution of officially or unofficially produced goods, illegal use of state resources, the appropriation in one or another illegal form of profits from the sale of goods or services, theft, fraud, racketeering, drug trafficking and other types of criminal activity. To determine the correlation between these sectors, one of the criteria for illegal revenues from foreign trade operations can be taken. Thus, according to expert estimates, shadow capital exports in 1991 amounted to USD 3.9 billion; in 1992 - USD 3 billion, in 1993 - USD 2.9 billion, in 1994 - USD 2.5 billion, in 1995 - USD 2.6 billion, which in general amounted to approximately $20 \%$ of the total cost of the goods and

\footnotetext{
${ }^{5}$ Радченко А. Незалежність.09.08.95.
} 
services export in that year. It should be noted that the shadow economy was a source of income of at least $75 \%$ of the population, when the foreign economic operations that were carried out for benefit of people did not even make up $1 \%$ of the population of Ukraine.

Certain notions about the scope of the criminal sector of the economy were given by official statements of the leaders of Ukrainian lawenforcement bodies. Thus, the head of the SSU V.Radchenko disclosed that $40-50 \%$ of the financial capital in Ukraine had a shadow origin ${ }^{6}$. Deputy Interior Minister Y.Vandin said that the currency turnover of shadow structures amounted to 8 to 10 billion dollars ${ }^{7}$. Vice Prime Minister V.Durdynets reported that for 9 months of 1995, Ukraine exported barter goods at USD 1.98 billion. More than USD 1 billion was left abroad ${ }^{8}$. These and other indirect indicators testified that the criminal sector of the shadow economy was a significant part of the economy and, according to some experts, was at least half its volume in general.

Here are the main conclusions based on the analysis of the shadow economy in Ukraine as of 1995:

1. The state loses the possibility of a real economy management, since more than half of economic activity is informal in nature and it is not subject to state regulators. Key state authorities lack knowledge of objective macroeconomic indicators. For example, it is considered that in 1994 gross domestic product accounted for 38.9\% of GDP in 1989. In reality, it was $74.3 \%$. This deforms the understanding not only the people, but also the state officials about the objective state of the economy and it also complicates the formation of an effective economic policy.

2. The shadow economy destroys the economic system of the state. Concentrated capital is not aimed at investing in national production, it cannot be used to support social infrastructure and it objectively contributes to the growth of the pressure on tax, which, in its turn, drives economy even more into the shadow.

3. The shadow economy has an anti-national character; it interferes with the formation of a large legal national capital. The main free financial resources formed in this sector are sent abroad to ensure their protection. The national economy is depleted, while simultaneously investing in the economies of other states. According to expert estimates,

\footnotetext{
${ }^{6}$ Радченко А. Незалежність.09.08.95.

${ }^{7}$ Вандін Ю. Фінансова Україна. 25.07.95.

${ }^{8}$ Дурдинець В. Голос України. 25.11.95.
} 
from 1991 to 1995 about USD 15-20 billion was illegally exported from Ukraine. The shadow economy has created a certain investment vacuum, which began to be filled with foreign capital, primarily from the CIS states. It put the national economy not only under significant external influence, but also led to serious political consequences.

4. Shadow economy corrupts society. It deforms the consciousness of people and makes them be accustomed to the ignorance of the rules established by the state and leads to legal nihilism. New market relations are identified with unlawful activity by the public consciousness, which forms the psychological resistance to reforms as a result.

5. The shadow economy is the economic and financial basis for the formation of a parallel state power infrastructure.

At that time, political power was not able to inflict a devastating blow on the Fifth Estate without limiting the scale of the shadow economy and, in particular, its criminal part. In turn, the shadow economy cannot be brought under control by the efforts of law enforcement bodies or as a result of a one-time political or economic campaign of any level of activity.

The shadow economy can be narrowed only as a result of deep economic reforms and radical changes in the current economic regime. This is confirmed by the practical experience of the government that ruled at that period of time. Thus, the abolition of quotas and licenses in foreign economic activity, the fixation of the exchange rate, the alignment of domestic prices and prices in the international market on a number of types of products actually eliminated the whole scope of the sphere where excessive shadow capital was formed. At the same time, the national economy of the state was losing the necessary resources.

The first group of these changes is connected with the elimination of the transit status of the former state-owned property. This property was in fact no longer state-owned. But it did not yet receive other owners as well. In fact, it was managed by the heads of enterprises, ministries and departments, the regional elite, representatives of the higher echelons of the state, who also accumulated their own capital at its expense. That is why in Ukraine, the most profitable business is political power, as it was before and it is nowadays too.

Let's consider what processes are a real measure of criminal power in Ukraine in the years reviewed. The volume of capital illegally exported 
abroad during 1995 amounted to approximately USD 15 to 20 billion. According to the then deputy head of the SSU, A.Belyaev, $60 \%$ of the capital was in the hands of criminal structures. According to the US FBI data, in 1992-1993, organized criminal groups (racketeer-criminal groups) of CIS countries illegally took more than USD 15 billion to the West. For comparison, it can be noted that the total budget of the General Prosecutor's Office of Ukraine, the Security Service of Ukraine and the Ministry of Internal Affairs of Ukraine for 1996 amounted to UAH 79.7 trillion, or about USD 400 million. The Fifth Estate then established its own so-called tax system. According to the SSU, $90 \%$ of firms were under the influence of criminal groups. Mafia exercised total control over the commercial and largely over the state trading network. In this regard, the consumer was forced to pay $20-30 \%$ more for goods and services. The people actually had to maintain two parallel powers - legitimate and criminal ones at their own expense ${ }^{9}$. The shady clans actually controlled the distribution of all marketable products of Ukrainian production in one form or another, the volumes and types of which decreased annually, partially due to the nonreturn of funds that should have been used to reproduce production. For example, in 1994, Ukraine did not receive back USD 3.2 billion. $46 \%$ of the exported products remained unpaid. In early 1995, almost 600 enterprises had debts for export products ${ }^{10}$. Much of the capital accumulated in Ukraine was of a criminal origin. Thus, according to the Center for Sociological Studies data published in the magazine «Modernity», 82\% out of 1000 rich people stated that the main source of their capital was gained by theft, racketeering, currency transactions, and through public service, where they received bribes, holding positions in power. All this gives grounds for asserting that the criminal structures in Ukraine were disposing the funds comparable to the state's financial resources.

The criminal subculture integrated into all elements of the state system, society as a whole, and almost paralyzed their ability to self-defense. In fact, there is no influential social force in Ukraine that is interested in combating economic and political criminality and elimination of the shadow economy. Criminal-shadow activity is economically viable for managers of state enterprises and entrepreneurial circles. Illegally accumulated funds are used to finance a significant part of the media and dependent journalists. These

\footnotetext{
${ }^{9}$ Президент України Л. Кучма. Виступ на розширеному засіданні Координаційного комітету по боротьбі з корупцією та організованою злочинністю. Урядовий кур’єр. 02.02.1995.

${ }^{10}$ Дані Міністерства економіки України. Фінансова Україна. 15.08.95.
} 
financial sources are used directly or indirectly to finance practically all political parties and movements, irrespective of their political views. According to the SSU, $60 \%$ of Mafia clans had corrupt connections in various power structures and bodies. Almost $40 \%$ of enterprises and about $90 \%$ of commercial structures had connections with corrupt officials. More than $60 \%$ of average official's income is gained out of bribes. Attempts were made to integrate people directly from the criminal environment into the power institutions. According to the Ukrainian Center for Economic and Political Studies (UCEPS) experts, about 40 representatives of criminal groups were elected to take positions at different levels during the elections by people's deputies in the Autonomous Republic of Crimea. The following fact testifies that the authorities were used by the criminal elements to protect themselves against prosecution. According to the materials of the committees of the Verkhovna Rada of Ukraine during 4 years (1990-1994) more than 500 deputies of the local Councils, who were accused of committing crimes, were not brought to criminal responsibility, due to the fact that the Councils simply did not give permission to do that. Every sixth deputy who should have been prosecuted has committed two or more crimes. The absolute majority of these deputies, namely $83 \%$ are officials. In 1995, police detected crimes involving 106 civil servants, 79 law enforcement officers, and 30 MPs of various levels. There were well-known cases when some political organizations were formed directly on the basis of criminal groups. Quite a vivid example could be the creation of the Christian Liberal Party in the Autonomous Republic of Crimea, which was headed by a well-known criminal authority. Criminality from the CIS states, in turn, attempted to influence political forces in other states.

At that time, an extremely high level of social impoverishment of the population was formed in Ukraine. According to the Ministry of Statistics of Ukraine, $72.1 \%$ of the population was below the poverty line (UAH 4.8 million). The average salary (UAH 8 million) was officially received by $1.7 \%$ of the population. More than UAH 9 million was received by $4,5 \%$ of the population. However, these people did not have reliable mechanisms for countering criminality. Their expression of will during the elections had a single-action nature and it could not be guaranteed at all that the authorities would exercise their power to fulfill their own obligations stated at the election. At the same time, insecurity pushed people to illegal activities. Thus, according to a survey conducted by Socis-Gelap, in Ukraine at the end 
of $1995,16 \%$ of the population considered the possibility of making sufficient earnings through racketeering and theft, while another $15 \%-$ through foreign exchange operations.

As of December 1995, more than 580 thousand crimes were detected in Ukraine, which is $13.5 \%$ more than it was in 1994. Also, 1840 facts of bribery were detected, which is $19.4 \%$ more than in the previous year. At the same time, the number of economic crimes is constantly increasing: in 1991 there were detected 34,838 crimes $(+15.2 \%)$, in $1992-$ $36,860(+5.8 \%)$, in $1993-41,253(+11.9 \%)$, in $1994-57500(+13.5 \%)$, in $1995-57500(+34.4 \%)$ of crimes, respectively. Such statistics not only demonstrates the strengthening of the common-crime potential in the state, but it also confirms the fact that in 1995 the tendency of criminalization of society failed to be eliminated.

Mafia structures establish and develop international relations. This topic was the main one discussed at the Central European Symposium on the Fight Against International Organized Crime, held in December 1995 in Budapest. It was also noted there that «Eurasian» criminal groups that emerged in the post-Soviet space, became more powerful and they quickly expanded their activities to other states. The speakers at the conference emphasized that the actions of more than 300 criminal groups, which were formed on the territory of the former USSR, had international character.

According to the statements of the foreign press, after the unsuccessful attempt of the former acting Prime Minister of Ukraine Yuri Zvyagilsky to place in the one of Israeli banks about USD 300 million in cash, the government of this country in a closed meeting adopted a special decision, which provides for a significant intensification in counteracting the mafia from the former USSR. In this context, it is worth noticing the estimation of international organized crime group's activity, which was covered at the 9th Congress on Combating Crime held in May 1995 in Cairo under the auspices of the United Nations. It was also noted that organized crime uses state of the art technology and international connections much more effective than the states of the United Nations.

The stage of professional growth of organized crime, as well as the seizure and redistribution of public property in Ukraine. This was the period from 2000 to 2010, when the second and third stages of the privatization process took place in Ukraine. In our opinion, the first stage of privatization with the use of privatization securities, namely property certificates, was a 
sort of distracting maneuver (in particular, restructuring of social consciousness: socialism - capitalism) in the form of a mild transition to a large so-called "grab-what-you-can privatization" of the industrial complex of the state. This period is characterized by the absence of any systematical legal regulatory policy, support of state enterprises and conscientious entrepreneurs.

The stage of anchoring members of organized crime in the state authorities and administration bodies. Such penetration of organized crime group's members was aimed at influencing socioeconomic processes in the state to provide a reliable cover for criminal and other types of persecution for further unlawful activities aimed at the accumulation of profits. These processes began after the financial and economic crisis and the easing of the privatization process (2010), which led to inhibition and reduction of revenues from privatization into the budget. Taking advantage of its influence on imperfect administrative processes in the economy and finances in the state, organized crime combines its efforts with the aim of mercenary and violent influence on the state apparatus. Organized criminal structures become more hierarchical, conspired and penetrate their corrupt leaders at higher levels of state power. They seek to expand the scope of their illegal activities inside and outside of Ukraine. Organized crime integrates into highly profitable sectors of the economy and financial sector, which poses a real threat to the national security of Ukraine. Such a transformation of the organized crime groups has led to the fact that the state has no objective and honest information on the extent of organized crime and the level of corruption in the economy and finance. This is facilitated as well by dependent private media that allow organized crime not to uncover their activities, to avoid excessive attention from authorities, law enforcement agencies and the general public too. Special units for combating organized crime were eliminated. That was happening at a time when the economy and the financial system of the state became the core of organized crime. The systematic violation of economic market laws and legal norms pursues only one purpose - the further unlawful accumulation of capital and exorbitant enrichment. There was a change in the activities of organized criminal groups, as a result of which part of the shadow economy became an element of the symbiosis of criminal and legal economic structures. Organized massive theft of state material resources, including natural and financial resources as well, has been widely scaled up, as evidenced by recent 
criminal proceedings in Ukraine. The received illegal proceeds are washed off through a complex system of fictitious transactions and banking operations and settle on accounts in foreign financial structures or are refunded back to Ukraine as under the guise of investments or are used for buying real estate. To take possession of the Ukrainian land was their next step. The banking system of Ukraine has become a large monopolized and politicized closed-end structure that does not provide transparent and open financial reporting, and is not ready for the creation of audit and control committees for assessing possible financial risks. Non-transparent banking activity, non-compliance with the principle of social responsibility contributes more to speculative deals and quick super-profits. According to various estimates, in the period from 1991 and up to date, approximately USD 150 billion has been withdrawn from Ukraine to the offshores. Due to the use of offshores, our state loses 200-300 billion hryvnia annually. This is about a third of the state budget ${ }^{11}$.

To overcome organized crime and corruption, it is necessary to carry out the state policy of complex measures of socio-economic, organizational, managerial, legal nature on the basis of scientific research of these areas of social activity ${ }^{12}$, since even the super-amplification of law-enforcement bodies cannot become decisive and bring the desired results. We believe that market mechanisms at the present stage are effective stimulators of economic development, but they should be under public control. The profits and sizes of private property should be relevant to all forms and weight of the share of the joined efforts of each individual, but not just a small group of powerful, cynical, immoral and heartless people who, using such features, unfairly possess the results of common social work ${ }^{13}$.

\section{The Consequences of Corruption Crime in Ukraine}

In the years of his presidency, Leonid Kuchma also drew the attention of the public to the fact that corruption significantly influences

11 Грощі- на райських островах: Україна щороку втрачає третину держбюджету через офшори. URL: https://expres.online/archive/news/2018/01/12/280097-groshi-rayskyh-ostrovah-ukrayinashchoroku-vtrachaye-tretynu-derzhbyudzhetu.

12 Романюк Б. В. Безпека держави вимагає ефективних заходів боротьби з організованою злочинністю. Боротьба з організованою злочинністю і корупцією (теорія і практика). 2007. № 17. С. 3-21.

${ }^{13}$ Романюк Б.В. Трансформація сучасної організованої злочинності в Україні. Україна в системі сучасного міжнародного правопорядку та Європейської інтеграції: загальнотеоретичні та практичні проблеми: матеріали між нар. наук.-практ. конф. 18 груд. 2018. Київ: Таврійський нац. ун-т імені В. І. Вернадського. 2018. С. 156-158. 
the formation of state power in Ukraine. In the executive branch of government, such situation still exists mainly due to the fact that it is required to pay bribes for being appointed for a position in power, regardless of the business qualities of the candidate, and the decisive factor will be if the candidate has any relatives in power and if he is personally loyal enough (in other words: «does not matter who you are, but what is important-who is supporting you»). Manifestations of corruption in personnel policy at the higher levels of executive power are the most dangerous, since top-level executives create their own hierarchy of corrupt relations that penetrate through all levels of government. At the same time it will be impossible to take that or another position, based solely on the professional and personal qualities of the candidate. The decisive factors here are the benefits to be provided for being appointed, family and friendly relations with senior executives, and connections with other influential people. It happens often that the personnel decisions in the power structures are taken only formally. In fact, they are taken outside of their own offices by influential businessmen, heads of organized crime groups that control one or another region or area of activity. Such cases are reported by domestic and foreign mass media, government leaders, law enforcement agencies, and well-known politicians. Referring to the heads of law enforcement bodies, during his presidency of Ukraine, L.Kuchma stated: «There are about two and a half thousand criminal gangs registered in the internal affairs bodies. Just think about that! Two and a half thousand armed and ready for anything groups. However, you keep assuring the leadership of the state and society that you know well about them and their sphere of influence and that you handle the situation"14. Speaking about the corruption of the Ukrainian authorities, the People's Deputy of Ukraine O. Moroz pointed out: «The power is not exercised by the official structures, but by the oligarchs and clans instead" ". According to the Security Service of Ukraine, $60 \%$ of

\footnotetext{
14 Ленид Кучма. «Так дальше длиться не может». Выступление на заседании Координационного комитета по борьбе с коррупцией и организованной преступностью при Президенте Украины. 16 февраля 1998. Урядовий кур'єр. 19 февраля 1998. Коррупция в Украине:сущность, масштабы и влияние. Центр Разумкова. URL: http://www.razumkov.org.ua/ukr/article.php?news_id=200.

15 Читайте и сравнивайте, решайте и голосуйте. Коррупция в Украине: сущность, масштабы и влияние. Центр Разумкова. Крещатик. 29 октября 1999. URL: http://www.razumkov.org.ua/ukr/ article.php?news_id=200.
} 
mafia clans have corrupt connections in government bodies and administration $^{16}$.

At a meeting of the Coordinating Committee on Combating Corruption and Organized Crime under the President of Ukraine that was held on April 20, 2000 information on the business activities of parliamentarians was made public for the first time. According to the State Tax Administration, 364 people's deputies of Ukraine at that time had official income gained through commercial structures. Parliamentarians then headed 202 enterprises and were the founders of 473 enterprises. In general, people's deputies had a direct or indirect relation to the economic and financial activities of 3,105 enterprises. In 1999, these enterprises imported raw materials and consumer goods into the territory of Ukraine to the amount of UAH 13.2 billion (25.3\% of Ukraine's imports); and exported goods to the amount of UAH 5.2 billion (10.1\% of Ukraine's exports). According to the results of economic activity in 1999, the aforementioned enterprises had revenues to the budget in the amount of UAH 4.1 billion $^{17}$.

So, let's consider what really was going on in the state. Ukraine, having become independent state, proclaimed the foundation of a new democratic society with all the freedom of action, including the sphere of economic and other relations as well. The old state institutions of power were terminated or undermined and the staffing of state institutions was undergoing significant changes. Many new people came to the leadership of state institutions, who did not have any political or managerial experience and moral standards, but they had only desire to break anything old and build something new. With proclaimed freedom of action, uncontrolled processes in the development of public administration took place, which gave rise to chaotic processes in the economy, financial and social spheres. Production started to go down and there was a shortage of working capital in the state. Due to such lack of control in society, chaotic privatization together with other fraudulent actions of primary accumulation of capital started to boom. Soon after, redistribution of wealth through raider hijacking of enterprises started to take place.

16 Камлык М., Гега П., Вилецкий В. О проявлениях организованной преступности в производственной и управленческой сферах экономики. Борьба с организованной преступностью и коррупцией. 2000. № 1. С. 23-24.

17 Десятникова И. В. прошлом году наши граждане приобрели свыше пяти тысяч престижных «шестисотых» «Мерседесов» по цене от 100 до 300 тысяч долларов. Факты. 2000. 22 апреля. 
Under those conditions, a deep comprehensive study of the reasons for such a situation was not made and a general national program for building a new society in Ukraine was not worked out as well. Even the development of a mechanism for the decriminalization of capital and the work of well-known economists of Ukraine on the development of the renewed society economy was ignored ${ }^{18}$. In most cases, a new formation of society in Ukraine was build based on thoughtless introduction into practice, and often deliberate, purposeful and distorted copying of the capitalist systems of the Western states power. They also did not take into account the specific platform for their application, namely the postcommunist environment and ideology.

For the implementation of those rules, the performers without moral and ethics were required. And they were found of course. That was a new generation of Ukrainian, which grew and was formed in those specific conditions of imbalance of political, economic, social and cultural relations of the so-called period of Gorbachev's perestroika in the former USSR, during its collapse and building of an independent Ukraine as noble goal of many generations. However, besides the overall goal, the Ukrainian political elite did not have even a single clear and coherent strategic plan for national revival of an independent state, and had no clue about the structure and organization of the future society, cultural policy and ideas for unification of all the people of Ukraine.

The absence of the latter was replaced by the ideas of the private capitalist ideology of the accumulation of wealth, privileges, etc. without any rules. Instead, there were subjective views on the rules of state development in certain circles of the new generation of Ukrainians who imposed them on the society. Some «new Ukrainians» rather quickly became very rich and came to the power ${ }^{19}$ through following the new philosophy that they created themselves, i.e. that money is influential, though not possessing moral principles with that.

Very evident in this regard is the selfish accumulation of cash capital in the banking system that predominantly arose on loans in various and not always legitimate methods of state financial resources, and which was working only for its own benefit, but not in favor of the state economy and the welfare of the general population. For example, in 2004-2007,

\footnotetext{
${ }^{18}$ Будкін В. Постсоціалістична трансформація власності. Економіка України. 2007. № 2. С. 39-44.

${ }^{19}$ Вакарчук С. Майже весна или люди будущего. Зеркало недели. 2007. 8 дек. № 47. С. 2.
} 
banks' assets grew more than fourfold and amounted to more than USD 100 billion, which is an average of $60 \%$ per year and that is far exceeding nominal rates of economic growth. Banks attracted large amounts of cheap foreign credit resources, while in the domestic market they maintained high lending rates. The banking system is now a large monopolized and politicized closed-end structure that does not provide transparent and open financial reporting, auditing and scientific verification of possible financial risks. This is evidenced by the audio recording conversations that were made public by the mass media in 2015 on which the Deputy Chairman of the Board of the National Bank of Ukraine, Katerina Rozhkova, testified to corruption in banking system and undermining the national interests of the state, by the way, which was stated before by the people's deputy of Ukraine from the party «People's Front» Anton Gerashchen ${ }^{20}$.

Even the field of science became a sort of the certain brand for «new Ukrainians.» Let us recall the mass and undeserved appropriation of their degrees and scholarly titles. Having large funds or administrative levers, they forced scientists and members of specialized scholars and expert councils to work for them. Such applicants for prestigious scientific titles, due to their preoccupation or their intellectual potential, in fact, are not related somehow to the scientific achievements reported. But low-paid scientists have already come to terms with this situation, so they work for the customers of the dissertation and give their good to undeserved award to such applicants of scientific titles. The name of Kirilenko Katerina, the wife of Ukrainian politician V.Kirilenko, became a common name in Ukraine in connection with her doctoral dissertation on pedagogical sciences that she protected in 2015 , which caused a scandal in scientific circles and was recognized by many well-known scholars of plagiarism and pseudoscience. The case got so much publicity that this scientist got into the Ukrainian Wikipedia as a most famous plagiarist.

The fact that a low-paid person from science cannot always be free in his assessments and actions is a dangerous situation to the state and society. Fake scholars are illegally receiving wage supplements, posts and life-long social payments from the state, which is pure corruption. On the other hand, talented, but low-paid scientists are forced to leave Ukraine

\footnotetext{
20 Антикорупційні органи повинні відреагувати на оприлюднені записи розмов, імовірно, заступника голови НБУ Рожкової - Геращенко. URL: https://ua.censor.net.ua/video_news/416565/ antykoruptsiyini_organy_ povynni_vidreaguvaty_na_oprylyudneni_zapysy_rozmov_imovirno_zastupnyka_golovy.
} 
massively. Today, the salary of a scientist is equal to the street cleaner of a multistory building. This of course had an impact on the state of science in Ukraine. During the period of special popularity in the acquisition of academic degrees and titles, the number of scientists during the years of independence has grown almost three times, and the number of actual performers of the highest qualifications in scientific and technical works has decreased twice. As a result, promising directions of research were put on hold; scientific schools were destroyed, and so on. Even the National Academy of Sciences of Ukraine occupied only 677th place in the world in 2007 with regard to such an important indicator for the level of science as the citation of the works of scientists from all disciplines. According to Clarivate Analytics, in 2017 in the list of three and a half thousand most cited authors of the world the first place in the number of quotes in magazines from the Web of Science took the American scholars, the second - the Canadians, the third - the Chinese. And there was not even one representative of Ukraine ${ }^{21}$.

Cynicism of free actions in the accumulation of capital in spite of all morality and humanity has recently been manifested even in relation to natural and constitutional rights, life and health of man. Today, criminal business enrichment on human beings and drug trafficking is increasing rapidly, which threatens to whole nation.

Ukraine has not yet created a democratic system of public administration, which would be based on a clear separation of functions and powers of the branches of power, the division of positions in their structures into political and professional bureaucracy, an effective institute of selection, education and certification of personnel. This is evidenced, in particular, by fake competitive selections to senior management positions of civil servants to newly created anti-corruption government agencies about which so many complaints are received from the public and which raise so many questions to the authorities as well. We can recall as an example a scandalous appointment with gross violations of the law and bypassing the competition of the Deputy Minister of Justice of Ukraine, 30-year-old A. Yanchuk, who had no experience of managerial work. Later, again with the violation of the law, this candidate was subsequently appointed to a position of the President of the National Agency for the

\footnotetext{
21 Зомбі-академія: вчені-пенсіонери НАН України не витримують конкуренції у світовій науці. Їх утримання коштує близько 3,7 млрд. грн. url: http://texty.org.ua/pg/article/editorial/read/82121/ Zombiakademija_vchenipensionery_NAN_Ukrajiny_ne_vytrymujut_konkurenciji?a_srt=\&a_offset=7.
} 
Detection, Investigation and Asset Management of Corruption and Other Crimes $^{22}$. Thus, each of the branches of power tries to take a higher managerial level for taking preferential solutions in various ways and by different methods that are related to the administration of state property, finance, etc. Professional managers are completely controlled by nonprofessional politicians and serve them faithfully, but not the people who elect them for the honest management of the state's affairs in favor of people's interests. Therefore, in Ukraine they come to the post «... with the hope of obtaining unlimited powers in order to control the cash flows in the industry and promote their people" 23 .

It should be noted that the paternalistic policy of Soviet power destroyed the self-respect of people, also the faith that they can change something and that they have also some power, but at the same time it also generated the fears, so, as a result, they could only hope for the better future. The Russian and Soviet empires in order to manage Ukraine rather violently adhered to the principle of «divide and rule» in the aspect of imposing an ideology of contrasting the culture, customs and aspirations of the Ukrainian people of different parts of the state: east, west and south. Thus, various styles of national consciousness and culture of the united people groups in different regions were formed for building constant hostility and distrust in the state. Consequently, the process of building a new independent state was complicated not only by political and economic reforms, but other factors as well. In the young state of Ukraine there was not noted the required level of experience in building and managing the new society and the issues of religion, language, etc. had to be solved as well. A significant part of society, being very disappointed with the ineffective actions of the authorities, does not trust the courts, which should stand in defense of the rights of people. That's why citizens had to solve their problems seeking for help of the organized criminal structures and also by bribing officials, which really gave them so much needed quick results. The representatives of the state apparatus and

\footnotetext{
22 Іванова Наталя. Жити по-новому, призначати по-старому: кадрова політика Мiн’юсту. URL: http://ua.racurs.ua/634-jyty-po-novomu-pryznachaty-po-staromu-kadrova-polityka-min-ustu;

Бусол О. Як зберегти корупційні активи для Януковича? (деякі роздуми після Глобального форуму з повернення активів в США 4-6 грудня 2017 року). Юридичний вісник. № 50 (1171). 15-21 грудня 2017. C. 12-13.

23 Ведерникова И. Опасный диагноз, или почему государственная машина еле дышит? Зеркало недели. 2007. 15 дек. № 48. С. 4.
} 
citizens themselves are not fully aware of the pernicious nature of this method since they lack a proper legal culture. The harsh repressive measures will not bring the desired result in counteracting organized crime and corruption as well. It is necessary that the conscious people have a real understanding of the need for measures to be taken that would meet the compromise of the interests of all: the representatives of the government, business and other segments of the population.

When it comes to finding alleged ways of confronting these phenomena, in most cases there is deliberate focusing on allegedly objective difficulties in solving traditional issues of improving the form of activity, the structural organization of the law enforcement bodies and courts, and their departmental subordination. In certain cases, the intentional focus on such issues is obviously beneficial to those for whom a strong and effective law enforcement system is hampering the process of their own enrichment. On the other hand, they sometimes forget about the above-stated difficulties they stated themselves and they keep imposing their deliberate point of view while creating some new and special investigative bodies. Some politicians draft laws on the creation of additional law enforcement structures with the intent to manage them, because such a corporate structure is easier to be controlled and used in the fight against their political or business opponents. Such situation is possible only in the states with undeveloped democracies or, in general, with despotic forms of government. Here we can bring an example of such state as Guatemala and its anti-corruption court, which was declared by our domestic reformers for some reason as a leader in the fight against corruption $^{24}$.

The danger to the nation is the practice of replacing the positions of the first leaders by representatives of political parties. Such leaders interfere in personnel, operative-search and administrative-procedural activities often in the interests of their political party. The constant turnover of these politicians, their permanent perturbation, the dismissal of professionals, unwarranted staff cuts and obscure structural adjustments have led to the outflow of honest, professional staff, young ambitious

\footnotetext{
24 Бусол О. Зменшення рівня корупції не залежить від створення чисельних спеціалізованих інституцій, а від бажання й політичної волі влади». Юридичний вісник України. № 5 (1125). 3-9 лютого 2017. С. 12-13; Бусол О. Сербія, Словаччина і Гватемала- будемо наслідувати приклад? (щодо створення спеціалізованого антикорупційного суду в Україні). Конституційний процес в Україні: політико-правові аспекти. 2017. № 1. С. 3-11.
} 
officers of law enforcement and judicial authorities, and, consequently, the decline in the efficiency of their activities.

\section{CONCLUSIONS}

1. The political leadership of the young independent Ukraine failed to stop corruption. The above-mentioned processes have led to a national threat, to the impossibility to control the economy, to its exhaustion and they also contributed to the development of criminal add-ons. Criminality in Ukraine has become a political phenomenon. The Fifth Estate became equal to the state power as for certain parameters. The criminalization of economic and political life in Ukraine undermined its international prestige, created favorable conditions for strengthening authoritarian tendencies, and objectively became the basis for the emergence of a new totalitarian state.

2. The fight against shadow power and its criminal superstructure is directly linked to in-depth reforms, long and wide-ranging anti-criminal measures. However, the new political leadership underestimated the real power and capabilities of The Fifth Estate and the shadow economy, and it failed to fully implement the revealed political will to fight corruption and organized crime.

3. Law enforcement agencies were not able to independently eliminate corruption. From the very beginning it was necessary to involve the whole society in opposition to this phenomenon. It was also necessary to apply radically new technologies to fight with it, providing an appropriate financing for that.

4. The activities of the mass media (The Fourth Estate) should be independent and focused primarily on the analytical coverage of this phenomenon, on the creation of a supportive social and moral environment for combating it, and the formation of a truly civil justice.

5. Organized crime in Ukraine is highly professional and politicized. Oligarchic criminal clans, possessing material and financial resources, are luring the professional personnel, including law enforcement agencies to serve their interests. They created a specific system of power to support their activities, and therefore the state is at such a stage of development, when it requires extraordinary and effective approaches to counteract corruption. 
6. Reverse processes of budget expenditures for a certain political purposes, also the reduction of expenditures mainly of managerial categories of state employees and paramilitary structures, have led to poverty of both the population and government personnel, and it weakened the efficiency of the activities of state institutions as well. For insufficiently protected law enforcement officers it is hard to resist rich and secure offenders. Therefore, they need full social protection at the expense of the state budget not only during their period of service, but also on their retirement. Today, professional managerial staff and lawenforcement officers are forced to take jobs from private owners, and all their knowledge, experience and information of state importance they often have to pass not in the interests of the state and society, but in the interests of criminal organized structures instead.

7. We are currently witnessing moral impoverishment and distortion of public consciousness. For these reasons, Ukraine creates privileged conditions for freedom of action and the accumulation of wealth only by the rich. Under such conditions they act contrary to moral standards. Without proper control, especially from the law enforcement agencies, the most brave rich people conduct raider redistribution of property, finance contract murders, hide their profits from the state. Besides, they lobby for the rejection of laws on progressive taxes on property, real estate, etc. Acquired capital thus passes to citizens of other states $^{25}$. Therefore, now, the priority task for the Ukrainian authorities and society is to prevent further economic takeover of the state by the transnational mafia.

\section{SUMMARY}

Organized corruption in Ukraine has an ancient background. It has gone a long way from being primitive to becoming perfect one. At each stage of development there was a transformation of its form and essence. Many new people came to the leadership of state institutions, who did not have any political or managerial experience and moral standards, but they had only desire to break anything old and build something new. With proclaimed freedom of action, uncontrolled processes in the development of public administration took place, which gave rise to chaotic processes in the economy, financial and social spheres. The above-mentioned

\footnotetext{
${ }^{25}$ Романюк Б. В. Безпека держави вимагає ефективних заходів боротьби з організованою злочинністю. Боротьба з організованою злочинністю і корупцією (теорія і практика). 2007. № 17. С. 10-15.
} 
processes have led to a national threat, to the impossibility to control the economy, to its exhaustion and they also contributed to the development of criminal add-ons. Criminality in Ukraine has become a political phenomenon. The political leadership of the young independent Ukraine failed to stop corruption. Mafia structures establish and develop international relations. The Fifth Estate became equal to the state power as for certain parameters. The criminalization of economic and political life in Ukraine undermined its international prestige, created favorable conditions for strengthening authoritarian tendencies, and objectively became the basis for the emergence of a new totalitarian state.

\section{REFERENCES}

1. Романюк Б.В. Трансформація сучасної організованої злочинності в Україні. Україна в системі сучасного міжнародного правопорядку та Європейської інтеграції: загальнотеоретичні та практичні проблеми: Матеріали міжнародної науково-практичної конференції. 18 грудня 2018. Київ. Таврійський національний університет імені В. І. Вернадського, 2018. 204 с.

2. Нилов Александр. Цеховики. Рождение теневой экономики. Записки подпольного миллионера. «Сшитое дело». URL: https://public.wikireading.ru/79516.

3. Кримінологія. Спеціалізований курс лекцій зі схемами: Загальна та Особлива частини : [навч. посібн.] / Джужа O.M., Моісеєв С.М., Василевич В.В. К. : Атіка, 2001. 172 с.

4. Даніель Кауфман.Час-time,08.12.95.

5. Радченко А. Незалежність, 09.08.95.

6. Вандін Ю. Фінансова Україна, 25.07.95.

7. Дурдинець В. Голос України, 25.11.95.

8. Президент України Л. Кучма. Виступ на розширеному засіданні Координаційного комітету по боротьбі з корупцією та організованою злочинністю. Урядовий кур'єр, 02.02.1995.

9. Дані Міністерства економіки України. Фінансова Україна, 15.08.95.

10. Грощі- на райських островах: Україна щороку втрачає третину держбюджету через офшори. URL: https://expres.online/ archive/news/2018/01/12/280097-groshi-rayskyh-ostrovah-ukrayinashchoroku-vtrachaye-tretynu-derzhbyudzhetu. 
11. Романюк Б. В. Безпека держави вимагає ефективних заходів боротьби 3 організованою злочинністю. Боротьба 3 організованою злочинністю і корупцією (теорія і практика), 2007. № 17. С. 3-21.

12. Ленид Кучма. «Так дальше длиться не может». Выступление на заседании Координационного комитета по борьбе с коррупцией и организованной преступностью при Президенте Украины. 16 февраля 1998. Урядовий кур'єр. 19 февраля 1998. Коррупция в Украине:сущность, масштабы и влияние. Центр Разумкова. URL: http://www.razumkov.org.ua/ukr/article.php?news_id=200.

13. Читайте и сравнивайте, решайте и голосуйте. Коррупция в Украине: сущность, масштабы и влияние. Центр Разумкова. Крещатик. 29 октября 1999. URL: http://www.razumkov.org.ua/ukr/ article.php?news_id=200.

14. Камлык М., Гега П., Вилецкий В. О проявлениях организованной преступности в производственной и управленческой сферах экономики. Борьба с организованной преступностью и коррупцией, 2000. № 1. С. 23-24.

15. Десятникова И. В. прошлом году наши граждане приобрели свыше пяти тысяч престижных «шестисотых» «Мерседесов» по цене от 100 до 300 тысяч долларов. Факты, 2000. 22 апреля.

16. Будкін В. Постсоціалістична трансформація власності. Економіка України, 2007. № 2. С. 39-44.

17. Вакарчук С. Майже весна или люди будущего. Зеркало недели. 2007. 8 дек. № 47. С. 2.

18. Антикорупційні органи повинні відреагувати на оприлюднені записи розмов, імовірно, заступника голови НБУ Рожкової- Геращенко. URL: https://ua.censor.net.ua/video_news/416565/antykoruptsiyini_organy_pov ynni_vidreaguvaty_na_oprylyudneni_zapysy_rozmov_imovirno_zastupny ka_golovy.

19. Зомбі-академія: вчені-пенсіонери НАН України не витримують конкуренції у світовій науці. Їх утримання коштує близько 3,7 млрд. грн. url: http://texty.org.ua/pg/article/editorial/read/ 82121/Zombiakademija_vchenipensionery_NAN_Ukrajiny_ne_vytrymuj ut_konkurenciji?a_srt=\&a_offset=7. 
20. Іванова Наталя. Жити по-новому, призначати по-старому: кадрова політика Мін'юсту. URL: http://ua.racurs.ua/634-jyty-ponovomu-pryznachaty-po-staromu-kadrova-polityka-min-ustu.

21. Бусол О. Як зберегти корупційні активи для Януковича? (деякі роздуми після Глобального форуму з повернення активів в США 4-6 грудня 2017 року). Юридичний вісник. 2017. № 50 (1171). 15-21 грудня. С. 12-13.

22. Ведерникова И. Опасный диагноз, или почему государственная машина еле дышит? Зеркало недели, 2007. 15 дек. № 48. C. 4.

23. Бусол О. Зменшення рівня корупції не залежить від створення чисельних спеціалізованих інституцій, а від бажання й політичної волі влади». Юридичний вісник України, № 5 (1125). 39 лютого 2017. - С. 12-13.

24. Бусол О. Сербія, Словаччина і Гватемала - будемо наслідувати приклад? (щодо створення спеціалізованого антикорупційного суду в Україні). Конституційний процес в Україні: політико-правові аспекти, 2017. № 1. С. 3-11.

\section{Information about author:} Busol O. Yu.

Doctor of Juridical Sciences, Senior Research Officer, Head of the Department of Special-Legal Disciplines of the Scientific-Training Humanitarian Institute of the V.S. Vernadsky Taurida National University 33, John McCain str., Kyiv, 01042, Ukraine

Chief Researcher the Interagency Scientific and Research Center on Problems of Combating Organized Crime under the National Security and Defense Council of Ukraine 1, Solomenskaya square, Kyiv, 03035, Ukraine 